\title{
PERILAKU INDIVIDU DALAM ORGANISASI PENDIDIKAN
}

\author{
Siti Rodiah ${ }^{1}$, Ulfiah ${ }^{2}$, Bambang Samsul Arifin ${ }^{3}$ \\ UIN Sunan Gunung Djati Bandung \\ Sitirodiah182@gmail.com
}

\begin{abstract}
This study aims to describe aspects of human behavior in a particular group which includes aspects caused by the influence of organizations on bumans as well as buman influences on organizations including organizational behavior. The research method used is in the form of library research with a descriptive-qualitative approach. The results of this study illustrate that there are two factors that influence individual behavior towards educational organizations, namely internal factors and external factors. while the variables of individual behavior analysis include psychological, physiological, and environmental. As a preliminary understanding to understand personal behavior properly, it is necessary to understand the inherent characteristics of the individual, including biography, personality, perceptual characteristics and attitudes. Al-Qur'an verses related to personal behavior become the foundation of educational organizations that humans have positive and negative potentials in behavior, and in essence the positive potential of humans is greater than their negative potential.
\end{abstract}

Keywords: Behavior, Individual, Organization, Education

\begin{abstract}
Abstrak : Penelitian ini bertujuan untuk mendeskripsikan aspek-aspek tingkah laku manusia dalam suatu kelompok tertentu yang meliputi aspek yang ditimbulkan oleh pengaruh organisasi terhadap manusia begitu juga pengaruh manusia terhadap organisasi termasuk dalam perilaku organisasi. Metode penelitian yang digunakan berupa studi kepustakaan (library research) dengan pendekatan yang digunakan berupa deskriptif-kualitatif. Adapun hasil penelitian ini menggambarkan ada dua faktor yang mempengaruhi perilaku individu terhadap organisasi pendidikan yaitu faktor internal dan faktor eksternal. sedangkan variabel analisis perilaku individu diantaranya psikologis, fisiologis, dan lingkungan. Sebagai pemahaman awal untuk memahami perilaku pribadi dengan benar, diperlukan pemahaman karakteristik yang melekat tentang individu, termasuk biografi, kepribadian, karakteristik persepsi dan sikap. Ayat-ayat Al-Qur'an yang berkaitan dengan perilaku pribadi menjadi tumpuan organisasi pendidikan bahwa manusia memiliki potensi positif dan negatif dalam berperilaku, dan pada hakikatnya potensi positif manusia lebih besar dari potensinya negatif.
\end{abstract}

Kata Kunci: Perilaku, Individu, Organisasi, Pendidikan 


\section{PENDAHULUAN}

Dalam setiap organisasi, manusia merupakan faktor utama yang sangat penting. Ketika manusia memasuki dunia organisasi maka itulah awal perilaku manusia yang berada dalam organisasi itu ${ }^{1}$. Sehingga permasalahan manusia terus berkembang sesuai situasi dan kondisi dan semakin sulit dikendalikan, akibatnya permasalahan organisasi dan khususnya persoalan perilaku organisasi semakin hari semakin berkembang.

Konsep perilaku dari individu perlu dipelajari, karena kepribadian pada dasarnya merupakan karakteristik psikologis dan perilaku dari individu yang sifatnya permanen, yang membedakan satu individu dangan individu lainnya. Pimpinan organisasi dituntut untuk dapat memahami kepribadian dari setiap individu agar pimpinan dapat mengetahui bagaimana cara terbaik untuk menghadapi mereka, dan dapat menempatkan mereka pada tempat yang sesuai, walau dalam kenyataannya dalam hal kesesuaian tenaga kerja yang dibutuhkan terkait dengan faktor individu sebagai tenaga kerja, organisasi tidak selalu benar mendapatkan dan menempatkan tenagan kerja yang benar-benar sesuai dengan harapan dan tuntutan dalam pekerjaan. Hal tersebut biasa karena individu benar-benar tidak sempurna ${ }^{2}$.

Ilmu perilaku organisasi tidak hanya dibahas dan digunakan dalam kegiatan industri dan komersial yang menghasilkan produk, tetapi juga dalam bidang pendidikan untuk menciptakan sebuah sistem pendidikan yang lebih profesional dan berkualitas $^{3}$. Perilaku organisasi (organizational behavior) sebagai suatu bidang studi yang berfokus pada isu-isu yang dipengaruhi oleh individu, kelompok dan struktur perilaku dalam organisasi, yang bertujuan untuk menerapkan pengetahuan dalam meningkatkan efektivitas organisasi pendidikan ${ }^{4}$. Selain itu dalam perilaku organisasi

1 Widiansyah, A. (2018). Peranan Sumber Daya Pendidikan sebagai Faktor Penentu dalam Manajemen Sistem Pendidikan. Cakrawala-Jurnal Humaniora, 18(2), 229-234.

${ }^{2}$ Danandjaya, K. (2020). Perilaku Individu Dalam Organisasi. Jurnal Literasi Pendidikan Nusantara, 1(2), $125-132$

${ }^{3}$ Sulistiyorini, S. (2021). Perilaku Individu dalam Lembaga Pendidikan Islam. An-Nuba: Jurnal Kajian Islam, Pendidikan, Budaya Dan Sosial, 8(1), 131-145.

${ }^{4}$ Khairul Maulana, Resume Perilaku Organisasi, (Makalah Sekolah Tinggi Manajemen Informatika dan Komputer STMIK Mercusuar, 2010), h. 7. 
terjadi interaksi dan hubungan antara organisasi di satu pihak dan perilaku individu lain. ${ }^{5}$

Pembahasan tentang perilaku organisasi kini telah berkembang seiring dengan berkembangnya aktivitas manusia dalam organisasi. Penelitian tentang perilaku organisasi sangat penting, karena perilaku individu manusia dalam organisasi memiliki dampak langsung ataupun tidak langsung dalam membantu organisasi mencapai tujuannya. Terdapat latar belakang psikologi dan ilmu sosial dalam artikel ini. Semua hal yang berhubungan dengan psikologi adalah ilmu-ilmu yang berkaitan dengan perilaku yang ada hubungannya dengan masyarakat yaitu lembaga pendidikan sebagai tempat di mana individu berkumpul, beraktivitas dan interaksi.

Individu dalam tatanan organisasi memiliki kompetensi, kepercayaan pribadi, kebutuhan, harapan, dan pengalaman masa lalunya yang berbeda-beda yang akan dibawa ketika memasuki suatu lingkunagan yang baru, dalam hal ini organisasi pendidikan. Dan organisasi yang juga merupakan suatu lingkungan bagi individu mempunyai karakteristik pula. Adapun karakteristik yang dipunyai organisasi antaranya keteraturan yang diwujudkan dalam susunan hirarki, pekerjaan-pekerjaan, tugastugas, wewenang dan tanggung jawab, sistem penggajian (reward system), sistem pengendalian dan lain sebagainya. Sehingga ketika karakteristik individu terintegrasi dengan karakteristik organisasi maka akan terbentuk perilaku individu dalam organisasi.

Berdasarkan penjelasan tersebut maka artikel ini berfokus pada pembahasan perilaku individu dalam organisasi pendidikan yang terdiri dari konsep dasar perilaku individu, faktor-faktor yang mempengaruhi perilaku individu, variabel-variabel analisa perilaku individu dan perilaku individu dalam organisasi pendidikan serta implementasinya dalam lembaga pendidikan.

${ }^{5}$ Fitriani Perilaku, Organisasi dan Kepemimpinan Sebagai Sebuah Sistem, Jurnal IAIN Bone 2018 


\section{METODE PENELITIAN}

Penelitian ini termasuk kedalam jenis penelitian studi kepustakaan (library research). Pendekatan yang digunakan dalam penelitian ini berupa deskriptif kualitatif, pendekatan deskriptif kualitatif digunakan untuk menkaji tentang perilaku individu dalam organisasi pendidikan. Data-data yang diteliti berupa buku, artikel jurnal, dan sumber-sumber lain yang relevan dengan judul penelitian berkaitan dengan perilaku individu dalam organisasi pendidikan. Peneliti mengumpulkan dan menganalisis datadata yang bersumber dari berbagai literatur, buku-buku, dan artikel jurnal yang membahas tentang pelilaku individu dalam organisasi terutama organisasi pendidikan.

Untuk mendapatkan data yang diinginkan dalam penelitian ini, maka teknik pengumpulan data yang digunakan yaitu teknik dokumentasi (documentary study). Prosedurnya yaitu (1) mengumpulkan, menghimpun dan menggali data tertulis atau cetak seperti buku-buku dan artikel jurnal yang motivasi kerja dalam organisasi pendidikan, (2) penulis menggabungkan kumpulan data-data tersebut menjadi satu kesatuan data yang dituangkan dalam hasil penelitian ${ }^{6}$. Adapun teknik analisis data yang digunakan adalah content analysis, atau menganalisa bagaimana perilaku individu di dalam sebuah organisasi pendidikan.

\section{HASIL DAN PEMBAHASAN}

\section{Perilaku Individu}

Pentingnya memahami perilaku individu dikarenakan setiap individu memiliki karakteristik-karakteristik yang berbeda-beda sehingga mempengaruhi pola dan sistem kerja organisasi ${ }^{7}$. Menurut Sopiah agar dapat memahami perilaku individu dengan baik, maka terlebih dahulu harus memahami karakteristik yang menempel pada indvidu. Adapun karakteristik yang dimaksud adalah ciri-ciri biografis, kepribadian, persepsi dan sikap ${ }^{8}$.

\footnotetext{
${ }^{6}$ Anisa Wahyuni, Elva Siti Fatimah, Bambang Samsul Arifin. (2021). Motivasi Kerja dalam Organisasi Pendidikan. AL-FAHIM: Jurnal Manajemen Pendidikan Islam, 3(1), 14-32.

7 Selanno, H. (2014). Faktor internal yang mempengaruhi perilaku organisasi. Jurnal Populis, 8(2), 44-56.

${ }^{8}$ Sopiah, S. (2008). Perilaku Organisasional. PT Andi Yogya.
} 
Pemimpin atau manajer organisasi manajemen harus Memahami perilaku pribadi sebagai dasar untuk mengelola orang-orang di dalamnya. Masalah perilaku pribadi menjadi salah satu masalah yang sangat rumit yang selalu dihadapi semua manajer di berbagai organisasi, oleh karena itu perlu mempelajari dan memahami sehingga dapat mencapai tujuan organisasi secara efektif dan efisien.?

Pola perilaku manusia mengalami sedikit perubahan. Dan setiap manajer secara alami ingin menimbulkan perubahan perilaku yang mengarah pada peningkatan Kinerja karyawannya. Perilaku manusia terlalu rumit untuk dapat dijelaskan dengan generalisasi yang dapat diterapkan pada sesama manusia ${ }^{10}$. Dan perilaku pribadi merupakan bagian dari pembahasan perilaku organisasi. Menurut Miftah Thoha, perilaku organisasi pada hakikatnya adalah merupakan hasil interaksi antar individu dalam organisasi maka untuk mengetahui perilaku organisasi dengan baik terlebih dahulu harus diketahui terlebih dahulu perilaku individu-individu yang ada dalam organisasi ${ }^{11}$. Perilaku organisasi merupakan ilmu pengetahuan yang membahas tentang dampak perseorangan, kelompok, dan struktur dalam perilaku berorganisasi dengan tujuan menerapkan pengetahuan mengenai hal-hal tersebut guna memperbaiki efektivitas organisasi. ${ }^{12}$

\section{Faktor-Faktor Yang Mempengaruhi Perilaku Individu}

Faktor-faktor yang mempengaruhi perkembangan individu ada 2 yaitu faktor internal dan faktor eksternal. yang termasuk dalam faktor internal yaitu Hereditas (keturunan atau bawaan) menurut ahli yang beraliran nativisme mengatakan bahwa faktor yang mempengaruhi individu semata-mata di tentukan oleh unsur pembawaan. faktor pembawaan adalah proses penurunan sifat-sifat atau ciri-ciri tertentu yang ada pada orang tua atau dari keturunan kerabat-kerabat terdekat. sifat bawaan ini sulit untuk dirubah udah menjadi kebiasaan atau keturunan dari sifat orang tuanya. Faktor internal yang mempengaruhi perilaku individu dalam organisasi diantaranya: motivasi, motivasi adalah keinginan untuk melakukan sesuatu dan menentukan kemampuan

${ }_{9}^{9}$ Sopiah, Perilaku Organisasional, (Yogyakarta: CV Andi Offset, 2008), h. 24

${ }^{10}$ J. Winardi, Manajemen Perilaku Organisasi, (Jakarta: Kencana Prenada Media Group, 2004), h. 198.

11 Arrafiqur Rahman, Pengaruh Perilaku Individu Terhadap Kinerja Pegawai Pada Kantor Wilayah Departemen Agama Provinsi RI, Jurnal Ilmiah Cano Ekonomos Vol.2.No.1 Januari 2013

12 Umam, K. (2012). Perilaku Organisai. CV. Pustaka Setia 
bertindak untuk memuaskan kebutuhan individu. Beberapa Teori mmotivasi yang diadopsi pada faktor yang mempengaruhi perilaku dalam organisasi salah satunya adalah teorimotivasi higienis. Teori Motivasi Higienis (Motivation-Hygiene Theory) diajukan oleh ahli psikologi Frederick Herzberg, dengan keyakinan bahwa hubungan individu dengan pekerjaan adalah sesuatu yang mendasar dan bahwa sikap seseorang terhadap pekerjaan akan sangat menentukan kesuksesan atau kegagalannya, Herzberg melakukan penelitian dengan pertanyaan, "Apa yang diinginkan seseorang dari pekerjaannya?” Dia meminta karyawan untuk menjelaskan dengan rinci situasi kerja yang membuat mereka merasa luar biasa baik atau buruk.

Adapun faktor eksternal, Kondisi lingkungan. Menurut ahli aliran empirisme berpendapat bahwa perkembangan individu sepenuhnya ditentukan oleh faktor lingkungan/pendidikan. Faktor atau kondisi lingkungan ini juga mempengaruhi perkembangan manusia. Lingkungan merupakan suatu tempat dimana kita saling membutuhkan atau saling berinteraksi antara manusia yang satu dengan manusia yang lain. Faktor eksternal antara lain; pendidikan; agama; kebudayaan; lingkungan; dan sosial ekonomi. Faktor tersebut sedikit banyak mempengaruhi perilaku seseorang, begitu pula dalam perilakunya di sebuah organisasi. Faktor-faktor ini dapat mempengaruhi perkembangan manusia mulai sejak lahir sampai meninggal dalam mempengaruhi ke arah yang lebih baik maupun yang tidak baik. Pendidikan. Secara luas pendidikan mencakup seluruh proses kehidupan individu sejak dalam ayunan hingga liang lahat, berupa interaksi individu dengan lingkungannya, baik secara formal maupun informal. Proses dan kegiatan pendidikan pada dasarnya melibatkan masalah perilaku individu maupun kelompok ${ }^{13}$.

\section{Variabel-Variabel Analisis Perilaku Individu}

Gibson dkk, percaya bahwa kerangka kerja untuk menganalisis perilaku individu perlu mempertimbangkan jenis variabelnya, seperti variabel psikologis, fisiologis, dan lingkungan. Variabel psikologi meliputi persepsi, sikap kepribadian, pembelajaran dan motivasi. Variabel fisiologis meliputi kemampuan fisik dan

13 Sulistiyorini, S. (2021). Perilaku Individu dalam Lembaga Pendidikan Islam. An-Nuha: Jurnal Kajian Islam, Pendidikan, Budaya Dan Sosial, 8(1), 131-145. 
kemampuan mental, sedangkan variabel lingkungan meliputi keluarga, budaya, dan lingkungan sosial.

Sebagai pemahaman awal untuk memahami perilaku individu, diperlukan pemahaman karakteristik individu. Adapun karakteristik yang melekat pada individu diantaranya memiliki ciri - ciri biografis, kepribadian, persepsi dan sikap ${ }^{14}$.

Karakteristik Biografis yaitu karakteristik yang berhubungan dengan pribadi seperti umur, jenis kelamin, dan status kawin dan masa kerja ${ }^{15}$. Kemampuan yaitu kapasitas individu untuk mengerjakan berbagai tugas dalam suatu pekerjaan. Kemampuan intelektual, merupakan kemampuan yang yang diperlukan untuk mengerjakan kegiatan mental. Misalnya: berpikir, menganalisis, dan memahami yang dapat diukur dalam bentuk tes (tes IQ) dan setiap orang punya kemampuan yang berbeda.

Persepsi, persepsi merupakan suatu proses penginderaan, stimulus yang diterima oleh individu melalui alat indera yang kemudian diinterpretasikan sehingga individu dapat memahami dan mengerti tentang stimulus yang diterimanya tersebut. Proses menginterpretasikan stimulus ini biasanya dipengaruhi pula oleh pengalaman dan proses belajar individu.

Sikap, sikap merupakan pernyataan-pernyataan evaluatif baik yang diinginkan atau tidak diinginkan, mengenai objek orang atau peristiwa yang berhubungan dan dapat diketahui dengan melihat tiga komponen sikap yaitu: komponen kognitif, komponen afektif dan komponen perilaku. Komponen kognitif merupakan pernyataan nilai bahwa nilai demokrasi itu salah, komponen afektif adalah komponen yang merupakan segmen emosional dari sikap, sedangkan komponen perilaku sikap adalah komponen yang berfungsi untuk berperilaku dalam waktu tertentu terhadap seseorang atau sesuatu.

Kepribadian, keperibadian adalah organisasi dinamik dalam individu dan mempunyai sistem psikologis yang menentukan penyesuaian unik terhadap lingkungan. Keperibadian seseorang dipengaruhi oleh hasil dari keturunan dan lingkungan. Faktor keturunan ditentukan oleh faktor-faktor sejak lahir, misalnya

${ }^{14}$ Sopiah, Perilaku Organisasional, (Yogyakarta: CV Andi Offset, 2008), h. 13

${ }^{15}$ Robbins Stephen. Perilaku Organisasional. Jakarta: INDEK Kelompok GRAMEDIA. 2003, h. 46 
ukuran fisik, daya tarik wajah, jenis kelamin, tempramen, komposisi dan refleksi otot merupakan sebuah ritme yang dianggap dari orang tua yakni susunan biologis, psikologis, fisiologis inheren mereka. Akan tetapi jika keperibadian sepenuhnya ditentukan oleh faktor keturunan, ciriciri tersebut sudah ada sejak dilahirkan dan tidak ada pengalaman yang bisa menggantikannya, yang hal itu sangat tidak mungkin untuk merubah faktor tersebut. Padahal faktor keperibadian tidak sepenuhnya di tentukan oleh faktor keturunan. Diantara faktor yang memberi tekanan pada pembentukan keperibadian adalah kebudayaan dimana kita dibesarkan, pengkondisian awal, keluarga, teman, kelompok sosial dan pengaruh-pengaruh lain yang kita alami. Faktor lingkungan ini mempunyai peranan yang penting dalam membentuk keperibadian kita.

\section{Perilaku Individu Dalam Lembaga Pendidikan Islam}

Pengelolaan organisasi, dalam hal ini lembaga pendidikan Islam, seorang pemimpin atau manajer harus memahami karakteristik atau perilaku individu sebagai landasan untuk mengelola orang-orang yang ada dalam lembaga tersebut. Masalah perilaku individu merupakan salah satu masalah yang amat pelik yang dihadapi oleh semua manajer berbagai organisasi atau lembaga pendidikan Islam, yang oleh karena itu perlu sekali dipelajari dan dipahami agar tujuan organisasi dapat dicapai secara efektif dan efisien ${ }^{16}$.

Pola-pola perilaku manusia senantiasa mengalami perubahan, walupun sedikit. Dan setiap manajer sudah tentu berkeinginan untuk membuat perubahan dalam perilaku, yang dapat berdampak makin membaiknya performa para karyawan mereka. Perilaku manusia terlampau kompleks untuk diterangkan oleh sebuah generalisasi yang dapat diterapkan terhadap sesama manusia ${ }^{17}$

Untuk dapat menganalisa perilaku individu dalam lembaga pendidikan maka perlu diuraikan keterkaitan variabe-variabel yang berhubungan denga perilaku individu dan lembaga pendidikan yang antara lain variabel dasar perilaku yang meliputi

16 Sopiah, Perilaku Organisasional, (Yogyakarta: CV Andi Offset, 2008), h. 24

${ }^{17}$ J. Winardi, Manajemen Perilaku Organisasi, (Jakarta: Kencana Prenada Media Group, 2004), h. 198 
Karakteristik Biografis yang terdiri dari umur, umur individu pada masa ini termasuk pada golongan dewasa, kriteria untuk masa dewasa yaitu kemandirian ekonomi dan kemandirian dalam mengambil keputusan ${ }^{18}$. Untuk Jenis kelamin yang dimaksudkan disini adalah laki-laki dan perempuan, status perkawinan yaitu sudah kawin dan belum kawin, untuk masa kerja tentunya termasuk individu yang sudah bekerja karena menjadi bagian dari sebuah lembaga sebagai sumberdaya manusia yang melakukan aktivitas pada lembaga pendidikan.

Kemampuan yang dimaksudkan disini adalah pertama, kemampuan intelektual atau kognitif, yaitu kemampuan untuk melakukan aktivitas yang mengandalkan analisis logis. Dalam lembaga pendidikan Islam kemampuan kognitif berpikir kritis ini ini dicontohkan individu yang mampu memberikan sumbangan pemikiran untuk mengembangkan segala aspek yang berkaitan dengan lembaga, misalnya supaya lembaga tersebut menjadi lembaga pilihan dari peserta didik atau wali murid maka harus mampu memberikan pelayanan yang bermutu, yaitu menyediakan SDM yang unggul untuk mendidik peserta didik. Kedua, kemampuan fisik, yaitu kemampuan kekuatan atau ketrampilan untuk melakukan aktivitas yang membutuhkan stamina. Individu yang memiliki stamina dan cekatan sangat dibutuhkan untuk merespon masalah-masalah yang berkaitan dengan pengembangan lembaga pendidikan, misalnya ketrampilan individu untuk memanfaatkan media pembelajaran untuk peningkatan prestasi peserta didik

Kepribadian,merupakan faktor keturunan dan lingkungan bisa berubah karena kondisi dan situasi dan ditambah dari faktor situasional. Sedangkan karakteristik kepribadian individu yang agresif dalam lembaga pendidikan Islam lebih pada respon cepat terhadap situasi dan kondisi yang ada, misalnya memberikan usulan kegiatan tambahan untuk menunjang prestasi peserta didik. untuk individu yang pemalu cenderung tidak mengungkapkan pemikirannya secara langsung, pasrah adalah individu yang menerima apapun yang di perintahkan oleh atasannya, atau kepala madrasah. malas, ambisius, setia, jujur. Semakin konsisten karakteristik tersebut muncul di saat merespon lingkungan. Hal itu menunjukkan faktor keturunan

18 John. W. Santrock, Live -Span Development, Perkembangan Masa Hidup, Edisi 5 Jilid II, Jakarta: PENERBIT ERLANGGA, 1995, h. 90 
atau pembawaan (traits) merupakan faktor yang penting dalam membentuk kepribadian seseorang. Teori tipe kepribadian adalah pandangan ahli teori teori pekerjaan John Holland yaitu bahwa penting membangun keterkaitan atau kecocokan antara tipe kepribadian individu dan pemilihan karir tertentu. Holand mengajukan enam tipe kepribadian dasar yang berhubungan sengan karir yaitu realistik, investigatif, artistik, sosial, wiraswasta, dan konvensional. ${ }^{19}$

Pada masa dewasa awal sebagian besar individu memasuki beberapa tipe pekerjaan. Orang dewasa muda tidak sistematis dan tidak memiliki arah alam eksplorasi dan perencanaan karir mereka, sehingga mereka mugah sekali berubah. Siklus pekerjaan memiliki empat fase utama: seleksi dan masuk kerja, penyesuaian diri, pemeliharaan, dan pensiun.

\section{KESIMPULAN}

Perilaku pada dasarnya berorientasi pada tujuan, dengan kata lain perilaku biasanya didorong oleh keinginan untuk mencapai tujuan. Perilaku adalah semua tindakan yang dilakukan oleh seseorang dan tingkah laku tersebut dapat diamati. Dua faktor yang mempengaruhi perilaku individu terhadap oragnisasi pendidikan diantaranya faktor internal dan faktor eksternal. Faktor internal meliputi hereditas (keturunan), faktor yang diwarisi oleh orang tua meliputi bentuk atau struktur tubuh anak yang merupakan hasil percampuran gen orang tua, gen tersebut biasanya meliputi sifat-sifat yang diperoleh dari lingkungan, sifat orang tua, atau hasil belajar. Faktor eksternal meliputi lingkungan, pengalaman dan pendidikan.

Variabel analisis perilaku individu meliputi variabel psikologis seperti kognisi, kepribadian, belajar, dan motivasi. Fisiologis terdiri dari kemampuan fisik dan kemampuan mental, dan variabel lingkungan meliputi keluarga, budaya, dan kelas sosial. Agar dapat memahami perilaku individu dengan baik maka penting untuk memahami karakteristik yang melekat pada individu hal ini termasuk karakteristik biografi, kepribadian, persepsi dan sikap. Ayat-ayat tentang perilaku individu dalam Al-Qur'an menjadi dasar dalam organisasi pendidikan bahwasannya manusia memiliki

${ }^{19}$ Hendri Selanno, Faktor Internal yang Mempengaruhi Perilaku Organisasi, Populis, Volume 8 No.2 Oktober 2014, h. 44-56 
potensi positif dan negatif dalam perilakunya namun pada hakikatnya potensi positif manusia lebih kuat daripada potensi negatifnya.

\section{DAFTAR PUSAKA}

Danandjaya, K. (2020). Perilaku Individu Dalam Organisasi. Jurnal Literasi Pendidikan Nusantara, 125-132.

Maulana, K. (2010). Resume Perilaku Organisasi, (Makalah Sekolah Tinggi Manajemen Informatika dan Komputer STMIK Mercusuar.

Perilaku, F. (2018). Organisasi dan Kepemimpinan Sebagai Sebuah Sistem. Jurnal IAIN Bone.

Rahman, A. (2013). Pengaruh Perilaku Individu Terhadap Kinerja Pegawai Pada Kantor Wilayah Departemen Agama Provinsi RI. Jurnal Ilmiah Cano Ekonomos.

Santrock, J. W. (1995). Live -Span Development, Perkembangan Masa Hidup. Jakarta: PENERBIT ERLANGGA.

Selanno, H. (2014). Faktor internal yang mempengaruhi perilaku organisasi. urnal Populis, 44-56.

Selanno, H. (2014). Faktor Internal yang Mempengaruhi Perilaku Organisasi, Populis. 44-56.

Sopiah, S. (2008). Perilaku Organisasional. Yogyakarta: P'T Andi Yogya.

Stephen, R. (2003). Perilaku Organisasional. Jakarta: INDEK Kelompok GRAMEDIA.

Sulistiyorini, S. (2021). Perilaku Individu dalam Lembaga Pendidikan Islam. An-Nuba: Jurnal Kajian Islam, Pendidikan, Budaya Dan Sosial, 131-145.

Sulistiyorini, S. (2021). Perilaku Individu dalam Lembaga Pendidikan Islam. An-Nuba: Jurnal Kajian Islam, Pendidikan, Budaya Dan Sosial,, 131-145.

Umam, K. (2012). Perilaku Organisai. Bandung: CV. Pustaka Setia.

Wahyuni, A., Fatimah, E. S., \& Arifin, B. S. (2021). Motivasi Kerja dalam Organisasi Pendidikan. AL-FAHIM: Jurnal Manajemen Pendidikan Islam, 14-32.

Widiansyah, A. (2018). Peranan Sumber Daya Pendidikan sebagai Faktor Penentu dalam Manajemen Sistem Pendidikan. Cakrawala-Jurnal Humaniora, 229-234.

Winardi, J. (2004). Manajemen Perilaku Organisasi. Jakarta: Kencana Prenada Media Group. 